\title{
Relatedness of penicillin-resistant Streptococcus pneumoniae serogroup 9 strains from France and Spain
}

\author{
Anne-Marie Gasc, ${ }^{1}$ Pierre Geslin ${ }^{2}$ and A. Michel Sicard ${ }^{1}$ \\ Author for correspondence: Anne-Marie Gasc. Tel: +33 613359 71. Fax: +33613358 86. \\ e-mail: Gasc@ibcg.biotoul.fr
}

1 Laboratoire de Microbiologie et Génétique Moléculaire CNRS and Université Paul Sabatier, 118 route de Narbonne, 31062 Toulouse, France

2 Centre National de Référence des Pneumocoques, Centre Hospitalo-universitaire, 40 avenue de Créteil, 94010 Créteil, France

\begin{abstract}
Pulsed-field gel electrophoresis of the genomic DNA of penicillin-resistant strains of Streptococcus pneumoniae was carried out. Eleven clinical strains of serogroup 9 from different French towns and Paris hospitals were tested. The restriction enzymes Apal and Smal were used to digest intact chromosomes, and the fragments were resolved by field-inversion gel electrophoresis (FIGE). Five strains were similar using Apal and Smal. Four others were closely related when using Apal, and five others were closely related when using Smal. These results suggest that 10 of these strains are genetically related and have a clonal origin. The profile of the eleventh strain was completely different. Thus, in a given serotype the spreading of penicillin resistance can result from both clonal and independent events. Five strains had similar FIGE profiles to strains first isolated in Spain, suggesting that a resistant strain had spread from Spain to France.
\end{abstract}

Keywords: Streptococcus pneumoniae, fingerprinting, FIGE, penicillin resistance, serotype

\section{INTRODUCTION}

Emergence of penicillin-resistant pneumococcal strains is a major problem in antibiotherapy. Molecular methods are needed to determine the genetic relatedness of these strains. Fragmentation of Streptococcus pneumoniae genomic DNA with low-frequency-cleavage restriction endonucleases and separation of the fragments by fieldinversion gel electrophoresis (FIGE) provides a DNAfingerprint of strains. It has already been shown that FIGE profiles of independent strains are different whereas profiles of clinical isolates originating from a common ancestor are similar (Lefèvre et al., 1993). This typing method therefore seems suitable for testing whether several penicillin-resistant strains emerged independently or resulted from the spreading of one clone (Soares $e t$ al., 1993; Versalovic et al., 1993). Although more than 80 serotypes are known in $S$. pneumoniae most of the penicillin-resistant isolates belong to only a few serotypes, mainly 4, 6, 9, 14, 19 and 23 (Muñoz et al., 1991, 1992; Geslin et al., 1992). However, penicillin resistance is preferentially associated with certain serotypes depending upon the country of origin; serotypes 6 and 19 are mainly

Abbreviations: FIGE, field-inversion gel electrophoresis; MLEE, multilocus enzyme electrophoresis; PBP, penicillin-binding protein. found in South Africa, serotypes 2, 3, 6 and 14 are mainly found in Spain, France and Israel (Klugman, 1990), and serotypes 6, 9, 19 and 23 have been reported in a Barcelona hospital (Linares et al., 1992), and in other locations in Spain together with serotype 14 (Fenoll et al., 1991). The first serotype 9 strain resistant to penicillin was isolated in Spain in 1987 (Hakenbeck et al., 1991). Three other strains belonging to the same serotype were later isolated in the same country (Hakenbeck et al., 1991). They are resistant to similar penicillin concentrations and share the same multilocus enzyme electrophoresis (MLEE) pattern, showing that they had very likely originated from a unique clone (Sibold et al., 1992). In France, the first $S$. pneumoniae strain of serotype 9 bearing resistance to penicillin was isolated in 1988, and a rapid increase in penicillin resistance in other strains belonging to this serotype has been observed recently. The frequency of penicillin resistance in serotype 9 changed from $1.6 \%$ in 1988 to $15 \%$ in 1993 (Geslin et al., 1993). We have focused our investigation on serotype 9 .

\section{METHODS}

Bacterial strains and growth conditions. Bacterial strains and their relevant properties are listed in Table 1. Eleven French clinical isolates of penicillin-resistant $S$. pneumoniae were studied and compared with two Spanish strains. R6 (801) is a clone of 
the Rockefeller University Laboratory strain R36A. Strain $\mathrm{R} 36 \mathrm{~A}$ is itself a subclone of a type 2 strain which has lost its capsule (Avery et al., 1944). Strain 801 was generated from strain R6 by DNA induced transformation (Lefevre et al., 1979). The culture media have been described elsewhere (Claverys $e t$ al., 1980). Cultures were incubated at $37^{\circ} \mathrm{C}$ without aeration, the $\mathrm{pH}$ was checked at $\mathrm{OD}_{560} 0.3$ and $\mathrm{NaOH}$ was added to stabilize the $\mathrm{pH}$ at $7 \cdot 8$.

DNA preparation and restriction enzyme digestion. $S$. pneumoniae DNA embedded in agarose blocks was prepared by a method derived from that described previously for Haemophilus influenzae (Kauc et al., 1989). Cell cultures were grown to an $\mathrm{OD}_{560}$ of $0.3-0.5$, centrifuged at $5000 \mathrm{~g}$ for $10 \mathrm{~min}$ at $0{ }^{\circ} \mathrm{C}$, and washed with $1 \mathrm{M} \mathrm{NaCl}$ and $10 \mathrm{mM}$ Tris/ $\mathrm{HCl}(\mathrm{pH} 8.0)$. The cells were resuspended in the same buffer and adjusted to an $\mathrm{OD}_{560}$ of 6 . The bacterial suspension was warmed to $42-45^{\circ} \mathrm{C}$ and mixed with an equal volume of $1 \%$ low-melting-point agarose at the same temperature. The molten mixture was poured into Plexiglass moulds $(100 \mu \mathrm{l})$. After solidification, the cells embedded in agarose were lysed by addition of $0.1 \mathrm{M}$ EDTA, $10 \mathrm{mM}$ Tris $/ \mathrm{HCl}, 0.5 \%$ Brij, $0.2 \%$ deoxycholate, $0.5 \%$ Sarkosyl and incubated for $2 \mathrm{~h}$ at $37^{\circ} \mathrm{C}$. The agarose blocks were transferred to an equal volume of $0.25 \mathrm{M}$ EDTA, $1 \%$ Sarkosyl, $100 \mu \mathrm{g}$ proteinase $\mathrm{K} \mathrm{ml}^{-1}$ and incubated overnight at $50{ }^{\circ} \mathrm{C}$. They were suspended in TE buffer $[10 \mathrm{mM}$ Tris $/ \mathrm{HCl}$ (pH 8.0), $1 \mathrm{mM}$ EDTA] containing $1 \mathrm{mM}$ PMSF, incubated at room temperature for $1-2 \mathrm{~h}$ with gentle mixing, and washed three times with TE buffer.

For digestion of DNA, the agarose blocks were equilibrated with $1 \times$ restriction buffer. Each block was treated with $25 \mathrm{U}$ restriction enzyme (New England Biolabs or BRL) in $25 \mu \mathrm{l}$ buffer. The blocks were incubated with $S m a \mathrm{I}$ or $A p a \mathrm{I}$ for $2 \mathrm{~h}$, transferred to $100 \mathrm{mM}$ EDTA, and placed on ice for $15 \mathrm{~min}$. Before being loaded onto the gel, the blocks were melted at $62{ }^{\circ} \mathrm{C}$ for $10-15 \mathrm{~min}$.

FIGE of macrorestriction fragments. FIGE was performed in $1 \%(\mathrm{w} / \mathrm{v})$ agarose for $20 \mathrm{~h}$ at $8{ }^{\circ} \mathrm{C}$ at $5 \mathrm{~V} \mathrm{~cm}^{-1}$ in a $0.5 \times$ solution of Tris/borate/EDTA. Field inversion was supplied by a ramp (programmable power inverter; model PPI 200, MJ Research) that controls the time for the forward and reverse cycles. Programme A was used for 0.15-12.03 s in the forward and $0.05-4.01 \mathrm{~s}$ in the reverse direction. Programme B was used for $0 \cdot 3-30 \mathrm{~s}$ in the forward and $0 \cdot 1-10 \mathrm{~s}$ in the reverse direction. We commonly used $16 \mathrm{~h}$ of programme A followed by $4 \mathrm{~h}$ of programme B.

MIC determination. Exponentially growing cultures were diluted in C-medium. Bacteria were incubated in medium containing twofold serial dilutions of penicillin at $37^{\circ} \mathrm{C}$. The MIC was defined as the lowest antibiotic concentration that prevented visible growth (Laible \& Hakenbeck, 1987).

\section{RESULTS AND DISCUSSION}

To determine the genetic relationships of French isolates of $S$. pneumoniae we examined 11 strains from serogroup 9 isolated in different hospitals. These strains and their characteristics are listed in Table 1, which also includes two strains from serotype 9 that were isolated independently in Spain. Digestion with SmaI or ApaI produced about 20 fragments. The FIGE program used resolved 12-15 fragments well. When the DNA from each of these strains was compared, many of these fragments appeared to migrate to the same electrophoretic position (Fig. 1). To compare these strains we chose strain 19590 as the reference. The degree (percentage) of homology among the strains is given by the ratio of the number of fragments that are identical to the reference strain to the total number of fragments (Table 2). SmaI and ApaI restriction patterns of five French strains, 19590, 17700, 17365, 17534 and 17316, were identical both to each other and to the Spanish strain 676. The $A p a \mathrm{I}$ profile of strain 17114 and the $S m a I$ profile of strains 17438 and 665 were also identical to the reference. The ApaI profiles of strains 17438 and 18044 were identical but differed from the reference profile by one $55 \mathrm{~kb}$ band which disappeared. A possible explanation is that one site had been destroyed so that the corresponding fragment co-migrated with a larger fragment, which would mean that strains 17114 , 17438 and 18044 are very closely related to the reference strain; it is noteworthy that all of them are resistant to trimethoprim. Although homology between the $S m a \mathrm{I}$ and ApaI profiles of strains 18997 and 16415 was reduced, many bands were shared with the reference profile. Compared with the reference strain more mutations at restriction sites were evident. Therefore we suggest that strain 16415 also belongs to this family but has diverged more than the others. The profile of the last strain, 14493, was completely different from those of all the other strains (Fig. 1, Table 2). Likewise the profile of strain 801 is very different. This is not surprising since this strain is derived directly from strain $\mathrm{R} 6$ and shares the same restriction profile (data not shown). R6 is itself a non-capsulated type 2 strain, suggesting an independent origin from type 9 strains. The 10 most homologous strains are therefore members of the Spanish penicillin-resistant serotype 9 group that were isolated in 1988 in Barcelona (Sibold et al., 1992). These Spanish strains belong to a group of four strains from serogroup 9 that are penicillin-resistant and derived from a unique clone. The first strain of this group was isolated in 1987. They differ from each other only in minor properties. The Spanish strains assigned to two distinct clonal lineages apparently harbour identical mutant penicillin-binding proteins (PBPs), 1A-2B and 2X. Mutant PBPs could thus have been transferred from a penicillin-resistant serotype 23 into a penicillin-susceptible serotype 9 or vice versa (Coffey et al., 1991). This strongly indicates that the 10 French strains discussed above are also members of this serotype $9 \mathrm{~V}$ group. This conclusion was also reached by comparison of PBP profiles and by MLEE analysis of 9V strains from both countries (Hakenbeck et al., 1994). It is quite possible that the first strain isolated in 1987 spread in Spain and then in France. Genetic events such as mutations (Hakenbeck et al., 1991; Seroude et al., 1993) and/or horizontal exchanges must have occurred in at least two different lineages belonging to serogroup 9 to account for the 11 French penicillin-resistant strains investigated in this work.

These results show that the penicillin resistance that has recently emerged in France is not entirely due to the spreading of a single Spanish clone, but is also the result of independent events. Similar conclusions were drawn 
Table 1. Characteristics of S. pneumoniae clinical isolates

The first 11 French isolates were kindly donated by P. Geslin (Centre National de Référence des Pneumocoques, Créteil, France). For the French strains, the town of isolation or the hospital (in parentheses) in Paris is shown. The two Spanish strains 665 and 676 were a generous gift of

R. Hakenbeck (Max Planck Institute, Berlin, Germany). Resistance markers: Pe, penicillin;

Tp, trimethoprim; Em, erythromycin; $\mathrm{Cm}$, chloramphenicol. NT, Non-typable rough strain.

\begin{tabular}{|c|c|c|c|c|c|}
\hline Strain & Origin & $\begin{array}{l}\text { Isolation } \\
\text { date }\end{array}$ & Serotype & $\begin{array}{c}\text { Antibiotic } \\
\text { resistance } \\
\text { markers }\end{array}$ & $\begin{array}{c}\text { MIC of Pe } \\
\left(\mu \mathrm{g} \mathrm{ml}^{-1}\right)\end{array}$ \\
\hline 19590 & Le Mans & $10 / 1992$ & $9 \mathrm{~V}$ & $\mathrm{Pe} T \mathrm{p}$ & $0 \cdot 5$ \\
\hline 17700 & Paris (Debré) & $1 / 1992$ & $9 \mathrm{~V}$ & Pe Tp & 4 \\
\hline 17365 & Tours & $1 / 1992$ & $9 \mathrm{~V}$ & $\mathrm{Pe} T \mathrm{p}$ & 1 \\
\hline 17534 & Paris (Bichat) & $2 / 1992$ & $9 \mathrm{~V}$ & $\mathrm{Pe} \mathrm{Tp}$ & 4 \\
\hline 17316 & Paris (St Antoine) & $1 / 1992$ & $9 \mathrm{~V}$ & $\mathrm{Pe} \mathrm{Tp}$ & 2 \\
\hline 17114 & Créteil & $1 / 1992$ & $9 \mathrm{~V}$ & $\operatorname{Pe} T p$ & 1 \\
\hline 17438 & Brive & $1 / 1992$ & $9 \mathrm{~V}$ & $\mathrm{Pe} T \mathrm{p}$ & 2 \\
\hline 18044 & Brive & $3 / 1992$ & $9 \mathrm{~V}$ & $\mathrm{Pe} T \mathrm{p}$ & 0.5 \\
\hline 18997 & Paris (St Joseph) & $8 / 1992$ & $9 \mathrm{~V}$ & $\mathrm{Pe} \mathrm{Tp}$ Em Cm & 2 \\
\hline 16415 & Aulnay sous Bois & $11 / 1991$ & $9 \mathrm{~V}$ & $\mathrm{Pe} \mathrm{Tp} E \mathrm{Em}$ & $0 \cdot 5$ \\
\hline 14493 & Compiègne & $2 / 1991$ & $9 \mathrm{~N}$ & $\mathrm{Pe} \mathrm{Tp}$ & $0 \cdot 125$ \\
\hline 665 & Spain & 1988 & $9 \mathrm{~V}$ & $\mathrm{Pe} \mathrm{Tp}$ & 1 \\
\hline 676 & Spain & 1988 & 9 & $\mathrm{Pe} T \mathrm{p}$ & 1 \\
\hline R6 (801) & USA & 1947 & NT & Susceptible & $0 \cdot 05$ \\
\hline
\end{tabular}

(a)

\section{숭}

(b)

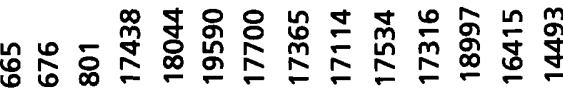
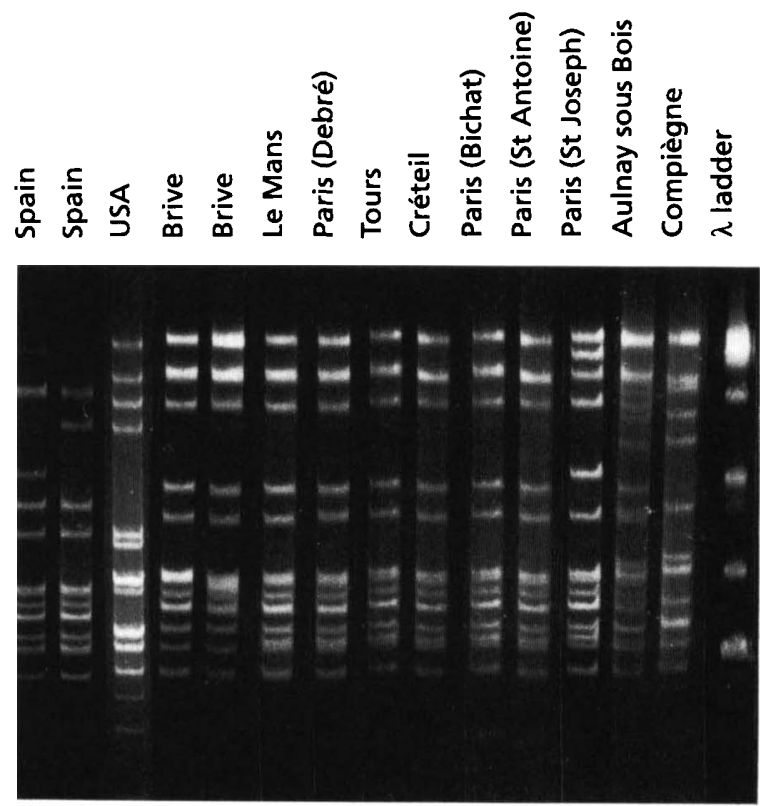
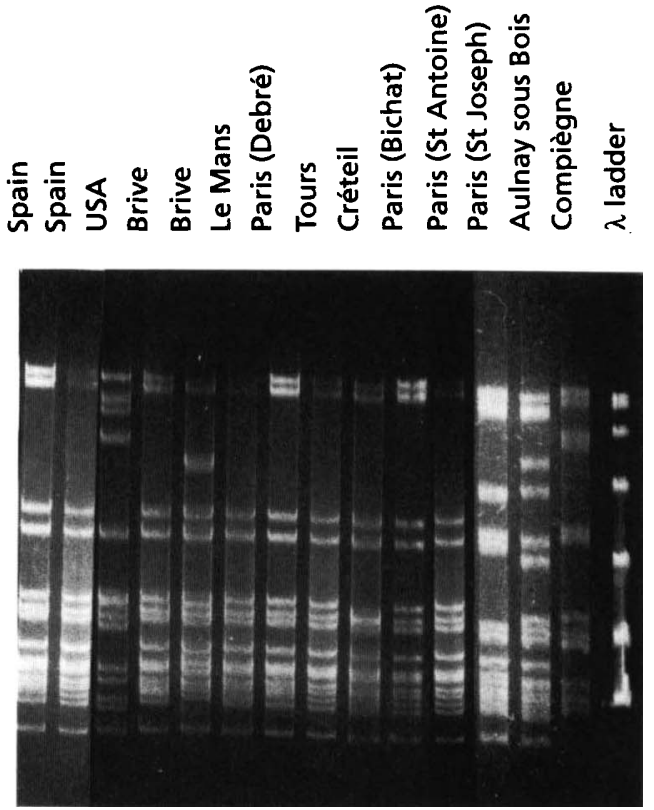

Fig. 1. FIGE separation of Apal (a) and Smal (b) restriction fragments of S. pneumoniae strains from serogroup 9 and from strain 801. A $\lambda$ ladder is included in the last lane. The marker sizes are 48.5, 97, 145.5, 194, $242 \cdot 5$ and $291 \mathrm{~kb}$. 
Table 2. Comparison between FIGE profiles of Apal and Smal restriction fragments

Strain 19590 is the reference strain. Percentage homology is the ratio of the number of restriction fragments that co-migrated with the reference to the total number of bands.

\begin{tabular}{|ccccc|}
\hline Strain & $\begin{array}{c}\text { No. of } \\
\text { co-migrating } \\
\text { Apal } \\
\text { fragments }\end{array}$ & $\begin{array}{c}\text { Percentage } \\
\text { homology }\end{array}$ & $\begin{array}{c}\text { No. of } \\
\text { co-migrating } \\
\text { SmaI }\end{array}$ & $\begin{array}{c}\text { Percentage } \\
\text { homology }\end{array}$ \\
\hline 19590 & 13 & 100 & 14 & 100 \\
17700 & 13 & 100 & 14 & 100 \\
17365 & 13 & 100 & 14 & 100 \\
17534 & 13 & 100 & 14 & 100 \\
17316 & 13 & 100 & 14 & 100 \\
17114 & 13 & 100 & 12 & 85 \\
17438 & 12 & 92 & 14 & 100 \\
18044 & 12 & 92 & 11 & 78 \\
18997 & 11 & 92 & 9 & 64 \\
16415 & 9 & 69 & 9 & 64 \\
14493 & 3 & 23 & 4 & 28 \\
676 & 13 & 100 & 14 & 100 \\
665 & 12 & 92 & 14 & 100 \\
801 & 6 & 46 & 5 & 35 \\
\hline
\end{tabular}

by MLEE analysis of resistant strains belonging to several serogroups (Sibold et al., 1992). Fingerprints of a large number of isolates will be required to determine more precisely how many independent clones participated in the emergence of penicillin-resistant strains from serogroup 9 in France and in other countries.

It is notable that within this group of 13 related strains, penicillin resistance varied by up to eightfold. This might mean that resistance genes had accumulated in a parental clone resistant to a low concentration of penicillin and were then selected by antibiotic treatments that vary from hospital to hospital. Of course it cannot be excluded that the first clone was a highly resistant one and that one or several of its resistance determinants had been transferred into other genetic lineages (Coffey et al., 1991). Another possibility could be reversions from high-level to lowlevel resistance, as we have observed in laboratory experiments (unpublished data). In hospital strains, multiple nucleotide changes do occur in penicillin-susceptible and -resistant bacteria. However, a point mutation might play a major role in modifying the level of resistance, an event that could be reversed. Answers to these questions must await a detailed analysis of the penicillin-resistance determinants of several strains sharing similar FIGE patterns. The rapid spreading of pneumococcal clones over large distances that also has been reported for other serotypes (Hakenbeck et al., 1994; Muñoz et al., 1991; Soares et al., 1993) raises the question of the nature of the carrier of these bacteria and the mode of transmission. The ability to trace a clone by DNA fingerprinting should facilitate our understanding of these processes.

\section{ACKNOWLEDGEMENTS}

We thank A. Carpousis for his kind help in preparing the manuscript. This work was partly supported by an INSERMBEECHAM grant.

\section{REFERENCES}

Avery, O. T., MacLeod, C. M. \& McCarty, M. (1944). Studies on the chemical nature of the substance inducing transformation of pneumococcus types. J Exp Med 79, 137-158.

Claverys, J. P., Roger, M. \& Sicard, A. M. (1980). Excision and repair of mismatched base pairs in transformation of Streptococcus pneumoniae. Mol \& Gen Genet 178, 191-201.

Coffey, T. J., Dowson, C. G., Daniels, M., Zhou, J., Martin, C., Spratt, B. G. \& Musser, J. M. (1991). Horizontal transfer for multiple penicillin-binding protein genes, and capsular biosynthetic genes, in natural populations of Streptococcus pneumoniae. Mol Microbiol 5, 2255-2260.

Fenoll, A., Martin Bourgon, C., Muñoz, R., Vicioso, O. \& Casal, J. (1991). Serotype distribution and antimicrobial resistance of Streptococcus pneumoniae isolates causing systemic infections in Spain 1979-1989. Rev Infect Dis 13, 56-60.

Geslin, P., Buu-Hoi, A., Fremaux, A. \& Acar, J. F. (1992). Antimicrobial resistance in Streptococcus pneumoniae: an epidemiological survey in France, 1970-1990. Clin Infect Dis 15, 95-98.

Geslin, P., Fremaux, A. \& Sissia, G. (1993). Infections à pneumocoques de sensibilité diminuée aux bêta-lactamines. In Epidémiologie de la Résistance de Streptococcus pneumoniae aux Bêtalactamines, en France et dans le Monde, pp. 55-71. Edited by C. Carbon, C. Chastang \& J. M. Decazes. Paris: Springer-Verlag.

Hakenbeck, R., Briese, T., Chalkley, L., Ellerbrok, H., Kallioloski, R., Latorre, C., Leinonen, M. \& Martin, C. (1991). Antigenic variation of penicillin-binding proteins from penicillin-resistant clinical strains of Streptococcus pneumoniae. J Infect Dis 164, 313-319.

Hakenbeck, R., Reichman, P. \& Sibold, C. (1994). Evolution and spread of $\beta$-lactam resistant Streptococcus pneumoniae. Klin Labor $\mathbf{4 0}$, 230-235.

Kauc, L., Mitchell, M. \& Goodgal, S. H. (1989). Size and physical map of the chromosome of Haemophilus influenzae. J Bacteriol 171, 2474-2479.

Klugman, K. P. (1990). Pneumococcal resistance to antibiotics. Clin Microbiol Rev 3, 171-195.

Laible, G. \& Hakenbeck, R. (1987). Penicillin-binding-proteins in $\beta$ lactam-resistant laboratory mutants of Streptococcus pneumoniae. Mol Microbiol 1, 355-363.

Lefèvre, J. C., Claverys, J. P. \& Sicard, A. M. (1979). Donor deoxyribonucleic acid length and marker effect in pneumococcal transformation. $J$ Bacteriol 138, 80-86.

Lefèvre, J. C., Faucon, G., Sicard, A. M. \& Gasc, A.-M. (1993). DNA fingerprinting of Streptococcus pneumoniae strains by pulsed-field gel electrophoresis. J Clin Microbiol 31, 2724-2728.

Linares, J., Pallares, R., Alonso, T., Perez, J. L., Ayats, J., Gudiol, F., Viladrich, P. F. \& Marlin, R. (1992). Trends in antimicrobial resistance of clinical isolates of Streptococcus pneumoniae in Bellvitge Hospital, Barcelona, Spain (1979-1990). Clin Infect Dis 15, 99-105.

Muñoz, R. T. J., Coffey, J., Daniels, M., Dowson, C. G., Laible, G., Casal, G., Hakenbeck, R., Jacobs, M., Musser, J. M., Spratt, B. G. \& Tomasz, A. (1991). Intercontinental spread of a multiresistant clone of serotype 23F Streptococcus pneumoniae. I Infect Dis 164, 302-306.

Muñoz, R., Musser, J. M., Crain, M., Briles, D. E., Marton, A., Parkinson, A. J., Sorensen, U. \& Tomasz, A. (1992). Geographic distribution of penicillin-resistant clones of Streptococcus pneumoniae: 
characterization by penicillin-binding protein profile, surface protein A typing, and multilocus enzyme analysis. Clin Infect Dis 15, 112-118.

Seroude L., Hespert, S., Selakovitch-Chenu, L., Gasc, A.-M., Lefrançois, J. \& Sicard, A. M. (1993). Genetic studies of cefotaxime resistance in Streptococcus pneumoniae: relationship to transformation deficiency. Res Microbiol 144, 389-394.

Sibold, K., Wang, J., Henrichsen, J. \& Hakenbeck, R. (1992). Genetic relationships of penicillin-susceptible and -resistant Streptococcus pneumoniae strains isolated on different continents. Infect Immun 10, 4119-4126.
Soares, S., Kristinsson, K. G., Musser, J. M. \& Tomasz, A. (1993). Evidence for the introduction of a multiresistant clone of serotype 6B Streptococcus pneumoniae from Spain to Iceland in the late 1980s. $J$ Infect Dis 168, 158-163.

Versalovic, J., Kapur, V., Mason, E. O., Shah, U., Jr, Koeuth, T., Lupski, J. R. \& Musser, J. M. (1993). Penicillin-resistant Streptococcus pneumoniae strains recovered in Houston: identification and molecular characterization of multiple clones. J Infect Dis 167, 850-856.

Received 28 July 1994; revised 2 November 1994; accepted 14 November 1994. 